Rubio C, Clua i Fainé M, Feixa C. (2018). Youth and social movements on the move: political engagement among young Spanish migrants in London. J Youth Stud. 22(2):223-39. DOI: 10.1080/13676261.2018.1495834.

\title{
Youth and Social Movements on the Move: Political engagement among young Spanish migrants in London
}

\author{
Clara Rubio, Montserrat Clua i Fainé, Carles Feixa
}

\begin{abstract}
Since the beginning of the economic crisis in Spain young people have migrated abroad looking for job opportunities. In the meantime, after the 15-M movement in 2011 Spanish society created various social movements hoping to make change happen, as well as the pro-independence movement in Catalonia that gathered strength as a response to the Spanish economic and political crisis. This paper analyses how Spanish young people in London, as transmigrants rooted in two different countries, engage with the politics of their home country through two transnational social movements in London: ANC England and the Maroon Wave London. The article describes both local movements (comparing their goals, structure and activities), showing the reasons that young Spanish migrants get involved and their experiences within them. It also rethinks the nature and modalities of young diasporic identities and political engagement in the global age through the experiences of the young people interviewed.
\end{abstract}

Keywords: youth migration, social movements, economic crisis.

The economic crisis has shocked the world since 2008, especially affecting Southern European countries, and one of the worst affected countries has been Spain. In this situation it is unremarkable that Spanish emigration has increased to the point that it has changed the country's demographic profile, becoming a country of net emigration rather than immigration as it used to be before the crisis. On the other hand, the economic crisis has also facilitated the appearance in Spain of new social movements that are questioning and criticising the political situation of the country. These social movements, like others that have appeared around the world (such as Occupy Wall Street), are seeking alternatives to the current democratic system and proposing other forms of political organisation, mainly through assemblies. Young people have been key in both trends, social movements and emigration, especially after having been affected by the economic crisis: youth unemployment rates have been among the 
highest in Europe, peaking in 2013 with $42.4 \%$ of 16 to 29 -year-olds unemployed (Eurostat).

This paper aims to put in dialogue youth migration and social movements, using data obtained from anthropological research conducted between 2013 and 2015 that explored the lives and narratives of young Spanish people in London. In particular, this article analyses how Spanish young people in London engage with Spanish politics through two local versions of Spanish social movements: ANC England (a British affiliate of the pro-independence Catalan National Assembly) and Maroon Wave London (a local variation of the Spanish 15-M movement). The results of the research test the theories about youth political engagement and Glick-Schiller's theory of transmigration, suggesting to what extent the activities that these young people engage in London are, or are not, transnational social movements.

\section{Spanish young people in London: engaging in politics from abroad}

Taking into consideration the high youth unemployment rates and the precarious job opportunities in Spain, it is not surprising that in the last decade many of these young people have decided to emigrate. Certainly, this situation is one of the reasons for emigration given by the informants during their interviews; they feel that this situation has forced them to "take the leap" en masse and try their luck abroad. The statistics show that European countries are their main destinations, the UK (13\%), France (10\%) and Germany (9\%) being the preferred European destination countries (González-Ferrer 2013). Nevertheless, as González-Ferrer (2013) and Navarrete (2014) show, it is very difficult to know how many Spaniards are currently living abroad due to a statistical under-registration of citizens living outside Spain, especially within the European Union.

Regardless how many emigrants there are, Rubio and Strecker (2017) point out that their stay abroad might be temporary, and they will return once the Spanish labour market gets better. Such temporary migration would be a strategy for middle classes: while they live in London, they avoid gaps they would have in their résumé if they stayed in Spain, and they also gain some skills that will improve their chances of finding better employment on their return (Rubio and Strecker 2016). Although some of those migrants find themselves in precarious labour conditions abroad, their overall life satisfaction is high. The authors link this high satisfaction to their understanding of their stay as temporary and as an opportunity to learn and improve themselves. Therefore, even if they consider themselves to be in a bad position, they believe that improvements will come in the near future - either abroad, through better job opportunities once they become integrated into the host society, or in Spain, through better job opportunities due to their international experience (Rubio and Strecker 2016). 
Furthermore, the global crisis and the resultant austerity policies have generated a new wave of social movements, following the "alter-globalisation" trends (Pleyers 2010). These "rhizomatic social movements" (Castells 2012) emerged from the ruins of neoliberal politics and (thanks to networked forms of communication) did so both online and offline. At the same time, the global protests of 2011 originated a new wave of research, in glocal squares such as Tahrir, Syntagma, Sol, Zucotti and Viaduto do chá. From these "engaged ethnographies", a new theoretical paradigm became visible: "technopolitics", where young people were at the centre of the "connective action" (Reguillo 2017).

In Spain, the critical situation of having less employment opportunities and more precarious conditions led young people to feel disillusioned. However, various political options have emerged since 2008 which aim to change the political structure: social movements such as the 15-M movement and new political parties such as Podemos. Following the terminology used by Feixa et al. (2009), we define these social movements as 'new new social movements'. The main difference between the 'new new social movements' and previous ones is the context (a more globalised world), a networking society and the use of the internet for internal organisation. They also are intergenerational and generally non-class and non-gender related.

Although Spanish 'new new' social movements integrate people of different ages, young people have had a distinguished role in their design and initial mobilisations, driven by frustration at their precarious situation and the impossible task of making the transition to adulthood (Muñoz and Santos 2014). This seems to contradict the generalised assumption that young people are not politically engaged. That belief was related to a prevailing assumption that political engagement can only be measured by electoral participation. In this sense, many studies have focused on understanding how the political socialisation process constitutes a first step for young people in shaping their electoral preferences (Hively and Everland 2009). A study by Ekström (2015) shows that young people start to become politically involved by speaking to their family and peers: people who are close to them and with whom they feel comfortable talking about political ideas.

According to the literature there are three ways to participate in politics: being active in socio-political movements, being involved in particular demonstrations or protests, or voting in elections (Galais 2012; Martín-Hernandez 2006; Mateos and Moral 2006). However, as Mateos and Moral (2006) argue, the institutionalised way to participate in politics is through political parties; this is why electoral participation has always been the standard measure by which to analyse the state of democracy within societies. Young people have always been considered as participating less in political elections than adults, which sometimes has been equated to the belief that young people are not politically engaged. However, various studies agree that, in general, young people vote less than adults but are nonetheless politically engaged in different ways (Campos and Martín 2014; Galais 2012; Mateos and Moral 2006; Martín-Hernández 
2006). Galais (2012) says that the way they become involved in politics is mainly through demonstrations, boycotts and civil disobedience. Following the classification proposed by Mateos and Moral (2006), Spanish youth have tended to opt for a nonelectoral and non-conventional way to participate in politics, instead of an electoral and conventional way. They would prefer to give voice to their political disagreement by being involved in socio-political movements and sporadic protests rather than giving up and being quiet.

In this case, youth migration and the 15-M movement happened at the same time in Spain, in a context of economic crisis. The new new social movements restored some belief in politics to the Spanish society. But what happened to the young people living abroad? How did young migrants experience the political mobilisation while they were not living in Spain? At what level did they engage with their home country's politics through transnational social movements (Glick-Schiller 1995)? In what sense has globalisation had an impact on social movements too? Smith et al. (1997) used the concept 'transnational social movement organisation' to talk about social movements that have activists in different countries and have some kind of international structure that organises the social movement internationally. We can relate the appearance of transnational social movements to a need in the migrants to get involved in the politics of their birth country:

'This is the moment in which large numbers of people, no longer rooted in a single place, go to great lengths to revitalise, reconstruct, or reinvent not only their traditions but their political claims to territory and histories from which they have been displaced' (Glick-Schiller 1995, 52).

Transnationalism has emerged as a response to the lack of understanding of migration processes, which has always been explained through assimilation and acculturation processes. The contribution of transnationalism to migration studies is, therefore, to consider migrants as social agents who, through their movements across borders, have an impact in host and home countries (Jiménez 2010). Guarnizo et al. (2003) also study how massive migration flows have stimulated what they call 'immigrant activism' and 'diasporic nationalism'.

In the 1990s Appadurai was already writing about a consequence of globalisation: 'groups are no longer tightly territorialised, spatially bound, historically unselfconscious or culturally homogenous' (Appadurai 1991, 191). In this sense Sassen (2007) argues that it is becoming more difficult to shape social movements at a nationstate level because their economic objectives are set worldwide. Transnationalism crosses the national borders that have been conceived by states as natural containers (Pries 1998, 115; 2002, 583; Levitt and Glick Schiller 2004, 1003) and approaches migration from the perspective of a more connected world.

Many authors have discussed how a more connected world affects social and political mobilisation (Della Porta and Tarrow 2005; Guidry et al. 2003) but not many 
of them have discussed how transmigrants engage with their birth country's politics from abroad. Following Glick-Schiller we understand transmigrants as 'immigrants who live their lives across national borders and respond to the constraints and demands of two or more states' (Glick-Schiller et al. 1995, 54). Glick-Schiller shows in an ethnography about migrants in the US (1995) how transmigrants tend to be politically engaged in both countries, rather than opting for just one of them. It seems that this is the case for the young Spanish migrants analysed in our research.

This article analyses the political engagement of Spanish young migrants in London through their participation in two assemblies in London: Maroon Wave London and ANC England. We have chosen London because in 2012 the United Kingdom was the preferred destination for Spanish people (González-Ferrer 2013). In addition, we have chosen Maroon Wave and ANC England because of the current significance of these two social movements in Spain and Catalonia, respectively. Maroon Wave (Marea Granate) was born in London in 2011, as an overseas offshoot of the 15- $M$ or Indignados movement. It was called 15-M London when it first appeared in 2011, and in 2013 evolved into Maroon Wave, aiming to be more inclusive of all the Spanish emigrant community in London. ANC England was born in 2011 and institutionalised in 2012; it is the English section of the ANC (Catalan National Assembly), one of the most important civic pro-independence movements in Catalonia today. We found it interesting to compare two different social movements that were born in the same historical context but have different origins and objectives, and to see how they have been internationalised by young migrants. Both movements are a clear example of what Della Porta and Tarrow (2005) called a 'diffusion process', the transnationalisation of social activism: ideas born in Spain are spread to another country, the United Kingdom. In this case, young Spanish migrants in London are the key focus of analysis, they being the agents spreading those ideas of social change.

In this sense, the case of young Spanish people in London challenges the concept of 'transmigration' as it is presented by the literature and demands a better understanding of their dual position. Migrants, as we have discussed above, are part of two states and, therefore, they feel attached to both societies. They are in-between two different countries: they are part of United Kingdom because their new home is now in London but, at the same time, they do not want to break their ties with their home country, Spain, which might make them feel that they are not entirely part of either of the countries they belong to. Nevertheless it is important to bear in mind the current political situation in Spain regarding the Catalan pro-independence movement. The secessionist demands have risen in Catalonia since the beginning of the economic crisis. In this sense, some of these youngsters have a third affiliation, Catalonia, which joins the game under the label of nation, interfering in their national engagement and identity. By focussing the study on young Catalan people in London we can analyse how the proindependence movement in Catalonia affects to the young people living abroad in contraposition to other Spanish young people who are not Catalan or who are not independence supporters. 


\section{Methodology}

The paper is based on information obtained from an anthropological fieldwork that took place in London between February 2013 and November 2015. During this period we applied four different qualitative and quantitative methods of data collection: in-depth interviews, surveys, participant observation and netnography. We have decided to combine different research methods in order to have deeper understanding about Spanish youth migration in London.

We carried out 42 in-depth interviews with young people between 18 and 30 years old living in London. Participants were recruited through activities organised by the Spanish community in London or through online forums. In-depth interviews allowed a better understanding of the political opinions of these young immigrants before and after the process of migration to London. Regarding the characteristics of these informants, 20 were young women and 22 young men; 29 had a university degree, 5 a professional training certificate, 7 had A-levels and 1 had secondary education. The lengths of their stays at the time of the interviews ranged from one week to eight years.

At the same time we carried out five in-depth interviews with people mobilised in the social movements in London that we met on different activities organised by these entities. Three of them were members of Maroon Wave London, including one of the founders, a person who had joined the movement recently and another who had joined the movement but was not an active member. We also did two interviews with members of ANC England: one was member of the Executive Committee and the other was an activist. The selection criteria used was sex ( 3 female and 2 male), previous experience in social movements ( 3 had previous experience and 2 had not) and length of stay in London ( 3 arrived during the crisis and 2 arrived before the Spanish economic crisis). The interviews aimed to understand the motivations of the activists in joining the social movements, their political opinions about Spain/Catalonia, and their political expectations. We could not interview young people involved in both social movements at the same time.

The following table summarises the main aspects of the participants: sex, previous experience in social movements, length of stay in London and role ${ }^{1}$.

[Table 1 near here]

Simultaneously we used data collected through an online survey addressed to young Catalans living in London through the Facebook page Catalans a Londres [Catalan people in London]. The survey had 35 questions about their motivations for

\footnotetext{
${ }^{1}$ The informants appear under a pseudonym in order to maintain their anonymity.
} 
migrating, their experience in the city (accommodation, jobs, relationships, social mobilisation and leisure activities) and 12 questions about socio-economic aspects. It was open from the $6^{\text {th }}$ until the $30^{\text {th }}$ of September 2015 and generated 201 responses in total (177 of them were verified as valid. If we part from an 'unknown population', we can assume that the 177 participants are representative for this collective with an interval of confidence of $+/-7.2$ ).

The following table summarises the main aspects of the participants' profiles: age, occupation and sex.

[Table 2 near here]

During the fieldwork we carried out ethnographic participant observation between January 2014 and September 2015 at different meetings and socio-cultural events organised by Catalan and Spanish people in London, paying particular attention to the different assemblies and events organised by ANC and Maroon Wave London. We also conducted participant observation via the internet (what Kozinets in 2009 called netnography) through different groups on Facebook, such as Catalans a Londres or Españoles en Londres.

\section{Youth migrants and the 'new, new' social movements: from Spain to London}

In this section we present the two social movements we have analysed, the Maroon Wave London and the Catalan National Assembly England. The information below has been elaborated from the data collected during the fieldwork and the in-depth interviews with the activists.

\section{Maroon Wave London}

The $15-M$ movement was born in Madrid on $15^{\text {th }}$ of May 2011 but has its origins in April 2011, when various smaller social movements such as Juventud sin Futuro [Youth without Future] created a campaign called Real Democracy now. The campaign aimed to organise different events/actions and demonstrations ahead of the local elections on $22^{\text {nd }}$ May 2011, as a way of participating in politics. Among their demands were a more democratic system, the end of the historic Spanish political bipartisanship (PP- PSOE) and the construction of a fairer democratic system that would include citizens' voices (Fernández-Planells et al. 2013). They also protested the obstacles to their transition into adulthood: Spanish young people were willing to have a full adult life but the system did enable them to do so, due to the precarious job conditions and high youth unemployment rates. As Mizen (2010) points out, young people are expected to "become socially accepted by adults" (Mizen 2010, 8) by following an institutional pathway that allows them to move from a state of dependence (mainly on parents and school) to one of independence. However, due to the economic crisis, they 
are in a position where they cannot achieve the full transition into adulthood. Juventud sin Futuro, therefore, protested against the socioeconomic situation that prevented them from becoming adults, pointing to the government as the main agent responsible for their precarious situation and their need to migrate.

Some Spanish migrants were in London when the 15-M movement took place in Spain in 2011. They wanted to be part of it, so they decided to have a demonstration in front of the Spanish Embassy in London that day, $15^{\text {th }}$ of May. During the first assembly in London, they decided to create 15-M London and camp in front of the Spanish Embassy on some weekends as a protest. A couple of years later, on $1^{\text {st }}$ June 2013, the activists decided in an assembly to transform the movement 15-M London into the Maroon Wave. The main reason was to be more inclusive and give space to migrants in London that did not feel comfortable under the umbrella of the 15-M movement. This new movement would preserve the main objective of $15 \mathrm{M}$ : to discuss politics and fight together against the causes of the economic crises. Yet it would also include a sense of community among Spanish migrants and fight for their rights as migrants, the right to vote while living abroad, for example. Maroon Wave as a social movement was born in London but it spread around the world very fast. Today there are 35 international nodes of Spanish Maroon Wave working together for the same cause and having regular online assemblies through a software called 'Mumble' that enables them to discuss issues that affect all the international nodes.

Maroon Wave London operate through three different elements. The first is the general assemblies, where the activists debate and decide organisational topics such as future actions, internode activities, roles, etc., and these tend to be less crowded than the second element. The second is the thematic assemblies, where the activists debate different topics of interest. During the fieldwork they have discussed topics such as a 'universal basic income', the 'degrowth movement' and 'immigrant rights'. One of the activists interviewed explained that these assemblies were created as a way to keep alive the 15-M's philosophy of promoting debate and learning from each other about social and political issues. The third element, the actions, consists of different activities that the assembly decide to do as a way to protest against a Spanish law or an unjust social or political situation. These actions can be either a copy of actions that other social movements perform in Spain, actions that are organised alongside other Maroon Wave international nodes, or actions that the London node decides to undertake on its own. Some of these actions can be coordinated with other British social movements, such as Occupy London. Maroon Wave London integrates with other groups that work on specific topics, such as the Women's Assembly (which is an assembly only for women and discusses topics of their interest) or the Precarious Office (which offers counselling to Spaniards in London in terms of working rights).

\section{ANC England}

The Catalan National Assembly (Assemblea Nacional Catalana, ANC) is a social movement created by civil society in Catalonia in 2012 that aims at the 
independence of Catalonia from Spain. It has a precedent in 2009, when Arenys de Munt (a little town near Barcelona city) organised a consultative and non-binding local referendum about Catalan independence from Spain.

In 2011, a group of Catalan migrants in the UK, began to talk about creating a local assembly of ANC in London. After several meetings they instituted the association in March 2012. They decided to call the movement ANC England in order to include Catalan migrants from outside London, although most of the assemblies and actions would take place in the British capital. ANC England has been, since then, one of the 37 international ANC nodes around the world. As a node, they have the right to be involved in all ANC decisions. Each node has to have regular assemblies were the members vote and give their voice to the central movement in order to be incorporated in the final decisions.

The first major action they organised was a Human Chain that took place on $11^{\text {th }}$ September 2013, as a local replication of the huge Human Chain that took place in the Catalan territory on its National Day. The ANC England organisation expected about 200 people and planned to do a small chain around Westminster. Finally, there were around 800 people involved and the chain extended over Westminster Bridge. They convened the event on their Facebook page but, as the informants explain, the best publicity for the event was word-of-mouth within the Catalan migrant community.

Since this major action ANC England has been carrying out the same actions as Catalonia on Catalonia Day. However, they have also been doing their own activities as a node. The goals of these activities were, firstly, to mobilise the Catalan proindependence people in London and, secondly, to spread their cause in order to internationalise it.

\section{Maroon Wave London vs. ANC England}

There are some similarities and differences between Maroon Wave London and ANC England. Both share the same context: they are from a country with a government engaged in austerity policies due to an economic crisis while, at the same time, different political scandals related to corruption have surfaced. In this sense both social movements are looking for a change, without cuts or corruption; however, the way they propose to do it is different. On the one hand, 15-M aims to rally all the Spanish citizens together and build a real democracy, where all voices can be heard (this is the reason why the different Waves were created). On the other hand, ANC proposes to build a better society for Catalan people by creating a new state of their own, as they do not believe that change will be possible if Catalonia continuing to be a part of Spain.

Furthermore, according to their internal organisation, both social movements are transnational because they integrate nodes from all over the world. Maroon Wave is certainly a horizontal social movement (in the terms of Arias 2007), because each node has equal power in the decision making within the social movement and they have open 
communication channels between the nodes. Hugo and Pere, activists from Maroon Wave London, explain how the social movement in London was very strong and consolidated when it was created in 2011. They explain how Maroon Wave London (and before that 15-M London) was the first international node of 15-M, from which many others were created. However, nowadays it is less strong and other nodes are leading the movement, such as Berlin. Marta, another Maroon Wave activist, explains that she only learnt about the London node through the Berlin one. By contrast, ANC has a vertical structure: the 37 international nodes count as one united voice in the general assemblies, which is communicated to the executive board through a representative, who integrates all nodes' voices into one.

Maroon Wave London is in a more in-between situation than ANC England, in the sense that it convenes actions which relate to social situation in both Spain and England. In the same way, Maroon Wave has more links with other international social movements than ANC England. In general, activists who take part on Maroon Wave also take part in other social movements. However, activists from ANC England usually are not mobilised in any other social movements.

One of the informants, Pere, explains that the line between social movements and political parties is fine, referring to Podemos, the political party which in 2014 emerged in Spain from the 15-M movement: in this case, activists saw a way to institutionalise the social will for change through the organised political action. Something similar happened in London. Podemos London appeared in February 2014, in response to the desire of Spaniards living in London to be part of the party. However, their fights and mobilisations were in various respects very similar to Maroon Wave's actions and some Maroon Wave activists were also Podemos members, which sometimes compromised their commitment to the social movement.

'Podemos acts as a social movement because it has not political representation in the [Spanish] institutions, therefore, the line is fine and the relationship sometimes is complicated. Sometimes we work for the same objectives, we share intentions, and we both want to convene actions at the same time and we do not know if it would be better to do it joint or not, it is complicated...' (Pere)

Although this tension between Maroon Wave and Podemos London was real, some of the members of Maroon Wave we interviewed were clear: they do not do institutionalised politics, they just do politics. Ultimately, Maroon Wave opted to convene their own actions independently of Podemos London, even though this might have caused problems or meant losing activists who preferred to work from Podemos rather than Maroon Wave. 


\section{Agoras and arenas of youth political engagement ${ }^{2}$}

In this section we present the findings of the research into the participation of young Spanish migrants in the "new new" social movements, according to three research themes: how the informants see their country once they have moved to London, their political engagement before and after migrating, and their participation in social movements in London.

\section{Youth and politics: how do they see their home country?}

Some of the questions in the interview with young Spanish migrants and Catalan/Spanish activists from ANC and Maroon Wave were intended to cover the way they see Catalan/ Spanish politics. All informants share a negative opinion about the political situation in their home country. When we asked them about their opinions on the social and political situation in Spain, various features were mentioned to be very negative in Spain and Catalonia, such as corruption, unemployment, the impact of the economic crisis on the social structure, and a general disillusionment towards the political system. All the young people interviewed pointed to the conflict between Catalonia and Spain as another concerning topic for them, especially (for the Catalan immigrants) the perceived anti-democratic treatment of Catalonia by the Spanish Government. Sergi, one of the young Catalan people interviewed, explains how serious the political corruption in his country is; corruption is usually associated with the Spanish government (as a result of cases like the Barcenas, Gürtel or Nóos scandals), but, in this particular case, he underlines that 'although Catalonia is considered to be different from Spain' there are corruption scandals there too, such as the cases of Millet or Pujol, among others. This informant states that the problem is not Catalonia or Spain, the problem is the conservative government that, in both cases, has allowed corruption to happen.

'I love my country [Catalonia] but there are bad things too! We can't forget that Catalonia is one of the countries with the highest corruption in Europe. The problem is that we still have in power the same Government who drove us into this disaster' (Sergi)

CMG9904, an activist from ANC England, says that what annoys her the most about Spain is its politicians, who make her cringe:

"The Parliament is worse than a nursery! All of them are: "you are bad", "you are worse" all the time! That's how they do politics... And it makes me cringe. All of them, I am not taking sides here. This embarrassment I am feeling, as well as many other citizens, needs to end, the situation must change' (CMG9904)

\footnotetext{
${ }^{2}$ Informants refer to Catalonia as a "country", though it is legally a region of Spain. The reason is that they consider Catalonia to be a nation and, as a consequence, they define Catalonia as a country. They usually refer to Spain as the Spanish State, so they call it a "State" rather than a country.
} 
The informants also point to the social consequences that the economic crisis has had in Catalonia, which go beyond the unemployment rates and the evictions. Marçal, for instance, points to the deep disillusionment and apathy of the general Spanish population, a situation that he agreed will have long-term consequences in the social structure.

'They are very apathetic, they do not want to do things, do not want to keep going... People over there are very sad, and it is normal because they are losing their jobs, their homes...' (Marçal)

Some of the interviewees also shared a sense of betrayal, which they feel is bidirectional: betrayal by the system of the young people, but also betrayal of their birth country by the young people when they emigrate. On the one hand, the system had promised them that the higher the level of education they achieved, the better the job they would have (in terms of power, prestige and salary). Most of them are educated to university level (undergraduate or Master's degree) but they could not find a job relevant to their studies in Catalonia/Spain so they had to migrate. They say that the system did not accomplish its promise so they feel betrayed. However, when they think about all the social problems that their compatriots have nowadays due to the crisis (high unemployment rates, people losing their homes, child poverty, etc.) they feel that they are the ones betraying their people. They would like to be there fighting for their rights, but they are in London fighting for their own future instead.

'I admire the people who decided to stay there and fight; they do not have references on how to change the situation. This is an act of bravery.' (Sara)

Young people show concern about betraying their own families and friends by being far from them.

'I do not like to think that in the near future my country will be as poor as the third world. It is my country! I want to be there helping to overcome the crisis and do things right.' (Laia)

\section{Youth engagement}

Although the literature reviewed states that there is apathy from Spanish young people towards politics, we have seen that this affirmation is not always right if we take into consideration non-electoral participation. One of the questions in the online survey was whether they were interested in voting in the Catalan regional elections on 27 th September 2015 or not. Only 2 people out of 172 were not interested in voting $(1.1 \%)$ and 6 people did not answer the question (3.5\%), as a consequence $95.4 \%$ of young Catalan people in London wanted to vote in the Catalan elections. The nature of the 27th September elections (related to the Catalan Independence issue) may introduce bias into the analysis of young Catalan people's political engagement if we take that figure as a reliable index of electoral engagement. However, it does prove that young Catalan people are not apathetic towards politics. 
M\&M, a young man who we interviewed during the fieldwork, states that he does reject politics as a whole:

'I did never like politics, I did never care about them, and I have always been a person who had radio at home, never TV. On the radio I always have music playing, never news, I do not want to hear anything about politics, robberies, bombs, wars... o whatever! This is all negativity and I do not want to attract negativity to my life so politics needs to be far from me' (M\&M)

However, when we asked him if he has ever been involved in any of the activities of ANC England or Maroon Wave London he replied:

'I did go to the Independence demonstration in Catalonia in 2012. If there was another one here [London] I would go as a part of the Catalan community in London' (M\&M)

This example shows how an apparent rejection of politics, which the subject has identified to be a negative feature in his life, has been falsified when we asked him about his involvement in 'new new' social movements. In this sense "politics", as a concept, is not well regarded by $M \& M$, but that does not mean that he is not politically engaged in not-institutionalised political activities such as demonstrations. There is a strong association between politics and political parties/elections in general, but, as we have seen before, politics extends beyond the institutional functions of governments into social movements, where young people have a key role.

From the 177 valid responses to the online survey, 4 people declared knowing only Maroon Wave, 98 ANC England, and 12 knew both movements, while 63 did not know any of them.

The survey also included questions about their level of involvement in social movements, which has been defined at two different levels. Level one is 'passive participation': people participating in events and actions that the 'core team' (the concept introduced by one informant to define the group of activists who regularly participate in social movements) planned during assemblies. And level two is 'active participation': people taking part in assemblies defining the movements' identity and their actions, which would be the 'core team'.

The table below shows how many people participated in social movements in London (ANC England and Maroon Wave). As we can observe, there are many more Catalans who knew and participated in ANC England than were involved in Maroon Wave London. 
[Table 3 near here]

\section{Youth mobilisation within the social movements in London}

The table below shows the number of young people who were previously involved in social movements in Catalonia and how many of them were (or were not) involved in social movements once they moved to London (ANC England, Maroon Wave or both). Migration process seems to have an impact on social-movement engagement. There is a decrement of young people who were mobilised in Catalonia and stayed mobilised in London: while 49 young people they had been involved in social movements when they were in Catalonia, only 22 of them affirmed that they were involved in social movements during their stay in London. Whereas in general there are more people who stop being active in social movements once they moved to London, 20 young people who had not been mobilised in Catalonia said they became involved in the ANC once they moved to London.

\section{[Table 4 near here]}

The difference between the people involved in social movements in Catalonia and the ones involved in London can be explained by the migration process itself. One of the young activists interviewed points out that not everybody is able to be an activist, especially in the midst of a migration process. Hugo, a member of Maroon Wave, stated that 'in order to commit yourself to a social movement you need time and peace of mind: a job, a place to live and free time' (Hugo). The activist pointed out that many of the Spaniards living in London have precarious job conditions and are working to achieve stability; therefore, committing themselves to social movements would be an impediment to meeting their immediate needs. These people, explains the activist, would take part in occasional actions or events to show their outrage and/or solidarity with the social movement, but they could not make a bigger commitment and be part of the 'core group' due to their personal and professional situation. Pere, another activist in Maroon Wave London explains how he was not able to join the 15-M movement when he was in Spain because he was preparing for his university entrance exams. Once he started university in London he was very interested in joining 15-M London, but he did not do so during his first year in the UK. He waited a year before fully committing himself to the movement because, he explains, he had to get integrated into British society first.

As part of the fieldwork we conducted participant observation during actions and assemblies in both social movements. We found that the activists in both social movements tend to be people between 20 and 40 years old, of different genders and social classes. In general, assemblies tend to have lower participation than actions or events. The actions/events and the thematic assemblies in Maroon Wave tend to be more multitudinous than the organisational assemblies; ANC assemblies are really small (between 6 and 15 people) when compared to the actions, which can mobilise up to 800 participants. What is the reason for this difference? As discussed above, more 
time and commitment is required in order to take part in the assemblies, which could be the reason that they have fewer people involved. The young Maroon Wave activists interviewed tended to have previous experience in political and social movements, while ANC England activists did not. Nonetheless, both movements coincide in experiencing greater levels of participation when something significant happens in Spain, such that Spanish migrants in London want to protest against it.

'More active people in social movements know about 15-M London, or Maroon Wave, and people who are less active in social movements get mobilised when something happens in Spain and want to protest.' (Hugo)

The activists interviewed, especially those who have been active longer, share an interest in engaging new members.

'I am glad there are people who suddenly say 'wow!' and wake up. The dialogue between the veterans and new people in social movements is very important and rewarding.' (Hugo)

However, in the case of Maroon Wave, Hugo states that not everyone can be an activist. There are different requirements, such as the non-violence principle or a commitment to the movement that not everyone is willing to share. Sometimes activists learn these requirements by being part of the movement; this is the reason why the dialogue between experienced and new activists is important for the movement.

\section{Final Remarks}

Young people in Spain started leaving the country from 2008, many of them feeling betrayed by their society and mistrustful of their political system. However, in 2011 the 15-M movement was created and part of the Spanish society rediscovered its hope for social change. Simultaneously, in Catalonia a pro-independence movement emerged as a way to create a new state and, also, to break with all the anti-democratic situations in which the Spanish government was mired, such as corruption and the unfair economical treatment of Catalonia, amongst other demands. Most of the participants in the present research arrived in London between 2011 and 2015, the period of time in which these social movements were most active in Spain. So, Maroon Wave London and ANC England have provided an opportunity for them to be active and get involved in Spanish/Catalan politics from London in a transnational way. However, we have found a relationship between the current nationalist demands in Catalonia and the way Catalan people get involved in social movements in London. Both Catalan and Spanish youth express disillusionment towards their social and political systems and a will to change them by building a better society. On the one hand, Spanish people focus this will on Maroon Wave London, a social movement that aims to change the Spanish reality as a whole. On the other hand, Catalan young people focus this political will on ANC England by building a new state of their own, which 
they believe that will support the social changes they are demanding. Therefore, their participation is conditioned by their own idea of country or nation, by the place they feel rooted to: Spain or Catalonia. Maybe this is the reason that we do not find people participating in both movements at the same time. It seems that Spanish immigrants tend to participate in one social movement at a time depending on their national political project. This also shows how the national conflict between Spain and Catalonia is transnationally replicated in London.

The activists we have interviewed believe in politics and want to take part in it, but they want to do it from the grassroots level. Of the young people that answered the survey, 53\% affirmed that they had been involved in at least one of the actions that either Maroon Wave or ANC England had organised in London between 2014 and 2015. In this sense we can confirm that there is a will among Spanish young people in London to participate in Spanish politics even when they are abroad. Therefore, some of the Spanish young people in London do not dissolve their bonds with Spain but reproduce the will to change Spanish society in their adopted location, and subsequently engage with either ANC England or Maroon Wave London, a split which reflects the conflict between Catalonia and Spain. They match Glick-Schiller's (1995) description of transmigrants, rooted in two different countries. We understand that their engagement with social movements is related to a hope and a will to change the situation in Spain by being involved in collective actions. This could also explain the intention to go back to their home countries in the near future, an intention that is shared by most of the young Spanish people interviewed.

The young people interviewed express very critical opinions about Spanish politics and society. However, they state that they participate less in political activism than they did in Spain. The survey results show that young people participated $6 \%$ more in social movements while they were living in Spain than they did once they moved to London. Although it is not a huge difference, this finding may be related to the precariousness they are experiencing in London. Hugo, an activist in Maroon Wave, pointed out that in order to be active in a social movement it is important to be settled in London and find time and energy to commit yourself to it. Many Spanish people are not yet settled down and find themselves in very precarious situations (long working days, long commuting distances, etc.) which do not allow them to commit to social movements. This is related to Lobera's theory of 'transversality with different intensities' (Lobera, 2015). He states that in 2011 three quarters of the Spanish population supported the 15-M ideology although not everyone became involved in the demonstrations and actions. Lobera argues that although the majority of the population agreed with the social movement's ideology there were diverse personal reasons why each citizen did not actively participate in its actions. This variability is what he called transversality - an ideology shared by a majority-with different intensities, which implies different levels of commitment. However, there is a connection between the different actions that are taking place in Catalonia/Spain and the participation in the actions that take place in London. The more those domestic actions appear in the media, 
the more Spanish young migrants participate in the actions in London. This can be understood as a consequence of the publicity the press bring to the actions that take place in Catalonia/Spain, but it can be also considered as a cause too: these Spanish young people in London participate in the actions because they are popular in their country and, at the same time, they get involved in the events in London as a way to be present at the actions that are taking place in their country.

Finally, we found that young Spanish migrants in London intend to return to their home country as soon as they find a job there. One of the reasons that they want to go back might be the importance of family bonds within Spanish society. However, we found that it is important to take into consideration the hope for social change as a key variable in understanding their willingness to return to their countries. It would be interesting to compare other youth migration flows from Southern Europe to Northern countries and also from Eastern Europe to the West to see if young people there are willing to return to their countries, and if the reasons are the same as for young Spanish people, or if, on the contrary, the expectation of a better Spanish/Catalan society is what mobilises young Spanish people abroad and makes them more willing to return to their country of birth.

\section{References}

Appadurai, Arjun. 1991. "Global ethnospaces: Notes and queries for a transnational anthropology." In Recapturing anthropology, edited by Richard Fox, 48-64. Santa Fe, NM: School of American Research Press.

Arias, Manuel. 2007. "Movimientos sociales transnacionales y orden' liberal.[Transnational Social movements and liberal order]" Paper presented at VIII Congreso Español de Ciencia Política y de la Administración Política para un mundo en cambio, Valencia, September.

Campos, Maria da Paz and Antonio Martín. 2014. "Descontentamento na Europa em tempos de austeridade: Da ação coletiva à participação individual no protesto social" [Dissatisfaction in Europe in austerity times: from collective action to individual participation in social protests]. Revista Crítica de Ciências Sociais, 103: 137-172.

Castells, Manuel. 2012. Networks of Outrage and Hope. Cambridge and Malden: Polity Press.

Della Porta, Donatella and Sidney Tarrow. 2005. "Transnational Processes and Social Activism: An Introduction." In Transnational Protest and Global Activism, edited by Donatella della Porta and Sidney Tarrow, 1-21. Oxford: Rowman \& Littlefield Publisher.

Ekström, Mats. 2015. "Young people's everyday political talk: a social achievement of democratic engagement." Journal of Youth Studies, 19 (1): 1-19. 
Eurostat. "Youth unemployment by sex, age and educational attainment level." Accessed 10 $0^{\text {th }}$ March 2016.

http://ec.europa.eu/eurostat/statisticsexplained/index.php/Youth unemployment.

Feixa, Carles, Inês Pereira, and Jeffrey S. Juris. 2009. "Global Citizenship and the 'New New' Social Movements: Iberian connections." Young, 17 (4): 421-442.

Fernández-Planells, Ariadna, Carles Feixa, and Monic Figueras-Maz. 2013. "15-M en España: diferencias y similitudes en las prácticas comunicativas con los movimientos previos." $[15 \mathrm{M}$ in Spain: differences and similities between its communication practices and previous social movements Última Década, 39: $115-138$.

Galais, Carol. 2012. “¿Cada vez más apáticos? El desinterés político juvenil en España en perspectiva comparada." [Getting more apathetic? Spanish young people's political indifference from a comparative perspective] Revista Internacional de Sociología, 70 (1).

Glick-Schiller, Nina. 1995. "From immigrant to transmigrant: theorizing transnational migration." Anthropological Quarterly, 68 (1): 48-61.

González-Ferrer, Amparo. 2013. "La nueva emigración española. Lo que sabemos y lo que no."[New Spanish emigration: what we know and what we do not] Laboratorio de Alternativas, 18.

Guarnizo, Luis Eduardo; Portes, Alejandro and William Haller (2003) 'Assimilation and Transnationalism: Determinants of Transnational Political Action among Contemporary Migrants', American Journal of Sociology, 108-6: 1211-1248.

Guidry, John A., Michael D. Kennedy, and Mayer N. Zald. 2003. Globalizations and Social Movements: Culture, Power and the Transnational Public Sphere. Michigan: The University of Michigan.

Hively, Myiah Hutchens, and William Eveland. 2009. "Contextual Antecedents and Political Consequences of Adolescent Political Discussion, Discussion Elaboration, and Network Diversity." Political Communication, 26 (1): 30-46.

Jiménez, Cecilia Inés. 2010. "Transnacionalismo y migraciones: aportaciones desde la teoría de Pierre Bourdieu.'[Transnationalism and migration: contributions from Pierre Bourdieu's theory] EMPIRIA. Revista de Metodología de Ciencias Sociales. 20: 13-38.

Kozinets, Robert. 2009. Netnography: doing ethnographic research online. London: Sage.

Levitt, Peggy and Nina Glick-Schiller. 2004. "Conceptualizing Simultaneity: A Transnational Social Field Perspective on Society." International Migration Review, 38 (3): 1002-1039.

Lobera, Josep. 2015. "De movimientos a partidos. La cristalización electoral de la protesta."[From movements to political parties. The electoral crystalization of protest] Revista Española de Sociología, 24.

Martín-Hernández, Alvaro. 2006. "Participación socio-política de los jóvenes españoles: medios y trayectorias." [Socio-political participation of Spanish Young people: means and trajectories] Consejo Superior de Investigaciones Científicas,. 
Accessed 15th September 2015. http://digital.csic.es/bitstream/10261/1672/1/dt0613.pdf

Mateos, Araceli, and Félix Moral. 2006. Comportamiento electoral de los jóvenes españoles.[Electoral behaviour of Spanish Young people] Madrid: INJUVE.

Mizen, Phillip. 2010. "Putting the Politics Back into Youth Studies: Keynesianism, Monetarism and the Changing State of Youth." Journal of Youth Studies, 5 (1): 5-20.

Muñoz, David, and Antonio Santos. 2014. "Hoy es el futuro. De la activación universitaria a las respuestas colectivas frente a la precariedad juvenile.'[Today is the future. From university activation to collective responses facing precariety] Revista de la Asociación de Sociología de la Educación, 7 (3): 658673.

Navarrete, Lorenzo, ed.). 2014. La emigración de los jóvenes españoles en el contexto de la crisis. Datos y análisis de un fenómeno difícil de cuantificar. [Spanish youth emigration in a context of crisis. Data and analysis from a phenomenon hard to quantify]. Madrid: Observatorio de la Juventud de España.

Pleyers, Geoffrey (2010) Alterglobalization. London: Pluto.

Pries, Ludger. 1998. "Las migraciones laborales internacionales y el surgimiento de espacios sociales transnacionales. Un bosque teórico-empírico a partir de las migraciones laborales México-Estados Unidos.’[International labour migration and the resurgence of transnational social espaces. A theoretico-empirical frame from labour migration between Mexico and United States]. Sociología del trabajo. 33: 103-129.

Reguillo, Rossana. 2017. Paisajes insurrectos. Jóvenes, redes y revueltas en el otoño civilizatorio [Insurgent landscapes. Youth, networks and revolts in the civilizational fall]. Barcelona: NED.

Rubio, Clara and Tanja Strecker (2017). “Aquí i allà: els plans de l'emigració de les persones joves universitàries i les realitats que es troben a Londres" [Here and there: migration plans of university students and realities they find in London]. In: L'emigrant 2.0. Emigració juvenil, nous moviments socials $i$ xarxes digitals, edited by Carles Feixa, Clara Rubio, Joan Ganau and Francesc Solsona, 153170. Barcelona: Col·lecions

Rubio, Clara and Tanja Strecker (2016). "Young Catalans living in London: 'You can make lots of money here but it is a very hostil city as well”. Youth Voice Journal (Accessed 19th October 2017) https://youthvoicejournal.com/2016/12/12/clararubio-2016young-catalans-living-in-london-you-can-make-lots-of-money-herebut-its-a-very-hostile-city-as-well/Sassen, Saskia. 2007. Una sociología de la globalización. [A sociology of globalization] Buenos Aires: Katz.

Smith, Jackie, Charles Chatfield, and Ron Pagnucco. 1997. "Social Movements and World Politics: A Theoretical Framework.” In Transnational Social Movements and Global Politics, edited by Jackie Smith and Charles Chatlfield, 59-79. Syracuse: Syracuse University Press. 
Wimmer, Andrea, and Nina Glick-Schiller. 2002. "Methodological nationalism and beyond: nation-state building, migration and the social sciences." Global Networks, 2 (4): 301-334. 
Table 1. Sex, age, length of stay in London and role of Spanish activists (elaborated by the authors).

Table 2. Sex, occupation and age of the informants of the online survey (elaborated by the authors).

Table 3. Participation in social movements among young migrants once they have migrated to London (elaborated by the authors).

Table 4. Participation in social movements among Spanish young people in London (ANC, MW or MW + ANC) according to their previous experience in Catalonia in social movements or other organisations such as religious institutions or NGOs (elaborated by the authors). 